\section{Regards sur l'économie allemande}

Bulletin économique du CIRAC

$68 \mid 2004$

Varia

\title{
Deutschland AG
}

STREECK Wolfgang, HÖPNER Martin (ed.), Alle Macht dem Markt?

Fallstudien zur Abwicklung der Deutschland AG

\section{(2) OpenEdition}

\section{Journals}

Édition électronique

URL : http://journals.openedition.org/rea/3637

DOI : $10.4000 /$ rea.3637

ISBN : 978-2-8218-0832-4

ISSN : 1965-0787

Éditeur

CIRAC

Édition imprimée

Date de publication : 1 octobre 2004

ISSN : 1156-8992

Référence électronique

«Deutschland AG », Regards sur l'économie allemande [En ligne], 68 | octobre 2004, mis en ligne le 29 avril 2009, consulté le 22 septembre 2020. URL : http://journals.openedition.org/rea/3637 ; DOI : https://doi.org/10.4000/rea.3637

Ce document a été généré automatiquement le 22 septembre 2020

(C) CIRAC 


\section{Deutschland AG}

STREECK Wolfgang, HÖPNER Martin (ed.), Alle Macht dem Markt?

Fallstudien zur Abwicklung der Deutschland AG

\section{RÉFÉRENCE}

STREECK Wolfgang, HÖPNER Martin (ed.), Alle Macht dem Markt? Fallstudien zur

Abwicklung der Deutschland AG, Coll. Schriften des Max-Planck-Instituts für

Gesellschaftsforschung Köln, vol. 47, Campus, Francfort/New York, 2004, 292 p.

1 Adieu, capitalisme rhénan? La montée en puissance de la doctrine de la shareholder value a profondément modifié la structure capitalistique des grands groupes allemands, dénouant le lien historique de la banque-industrie et générant de nouveaux modes de gouvernance. Mais elle est restée sans effet sur les relations industrielles, ainsi que le révèlent les travaux de recherche que l'Institut Max-Planck de Sociologie consacre à la question dans cet ouvrage collectif. (ib) 